\title{
Friedrich Heincke - the Right Man at the Right Time
}

\author{
P. Werner \\ Forschungsschwerpunkt Wissenschaftsgeschichte und Wissenschaftstheorie der För- \\ derungsgesellschaft wissenschaftliche Neuvorhaben $\mathrm{mbH}$; Prenzlauer Promenade \\ 149-152, D-13189 Berlin, Germany
}

Let me begin with some biographical remarks. Following these I will try to explain why it was Friedrich Heincke who was appointed director; why experts and officials of the Ministry of Culture thought that he was the right man for the job. And finally, I would like to answer the same question from a contemporary point of view. Judged by the standards of today, was he really the right man to found the Institute?

Friedrich Heincke was born in 1852. He was 40 years old, when he became Director of the first German Biological Station on the North Sea, on Helgoland. He occupied this position for about 29 years. He was very reluctant to hand it over to his pupil Wilhelm Mielck (1879-1933) in 1921, but a new German law forced him to do so. Until 1. 1. 1921 German professors usually retained their positions until they died. Under the new law they were obliged to retire at the age of 68 . The law caused enormous unease among the German "mandarins", as the American historian Fritz K. Ringer called them (Ringer, 1969).

Heincke was a good example of these. 1 have found letters from Heincke which indicate his bitterness. In this context, we should remember that it was a time of worldwide recession, and the government was considering closing the Station on Helgoland.

After 1921, Heincke was no longer officially Director, but in practice he continued to run the Station. He was an extraordinary person. He had a lot of contacts with scientists around the world, and knew important people in the Prussian government.

I have explained all this in my book about the history of the Biological Station of Helgoland (Werner, 1993). Why did Friedrich Althoff think Heincke was the right man? The answer to this question is closely connected with Althoff's influence (1839-1908) over Prussian science-policy in the 19th century. Althoff was not merely an administrator, he was the leader in a process of reform which helped to create a new and better landscape of German science. He became a symbol of this new science-policy. In 1882, he entered the Ministry as a low-ranking official, but soon had more influence than the Minister himself. Remember, it was the period of the so-called "second industrial revolution", the state was closely linked with industry, and research became very important and costly. Famous institutes were founded (for example the "PhysikalischTechnische Reichsanstalt", and others). Those institutes were not only founded with the help of the government, but also with the support of private sponsors. Althoff's task was 
to decide who would be appointed professorships in the universities and national institutes of Prussia. At that time Helgoland belonged to Prussia.

Althoff started very early to prepare the foundation of the Helgoland Station and gave much thought to the selection of scientists, particularly to the choice of a director. He corresponded with Anton Dohrn (1840-1909) who wrote: "Der Mann ist wichtiger als das Gebäude." (Dohrn 1891).

In my book (Werner, 1993) I explained the details of the discussion between the scientists and the Prussian Government about the foundation of this institute.

Who should be the director? This was the principal question. Ought one to look for a man with practical experience in scientific and commercial aspects of the fishing industry, or would it be better to choose someone with a background in fundamental research?

It was Ernst Ehlers (1835-1925) from Göttingen, who first made the proposal to found the Station. He hoped that the scientific programme of the new institute would be determined by fundamental research, and not by economic requirements. It is wellknown that the scientists who took part in the meeting of natural scientists ("Naturforscher-Versammlung") in Hamburg, drew up a memorandum promising that the new institute would help to solve the big economic problems of fishery. They sent it to those persons who had a lot of influence in politics.

The decision about who would be the director of the new institute, was influenced by a Board of experts. Althoff wrote a letter to his Minister, explaining why he had opted for the following experts:

1. Nathanael Pringsheim knew the Island of Helgoland well;

2. Franz Eilhard Schulze was one of the founders of the Biological Station in Graz, and therefore had a lot of experience in founding such a station;

3. Möbius was an expert in marine biology, particularly of the North Sea;

4. Viktor Hensen was well-known as a famous scientist in the field of plankton research. (Werner, 1993).

You will find more details in my book. When I examined the opinions of the different experts, I learned that Viktor Hensen (1835-1924) had played a special role in these deliberations. Althoff corresponded with him for a special reason. Among the experts on the Board, it was Hensen who had the greatest influence in the government. Historians know about his disputes with Ernst Haeckel (1834-1919), and about his famous and expensive excursion to the Atlantic Ocean. Hensen got quite a lot of money from the Prussian Academy of Science, and his work stood for a type of research which was oriented towards the needs of fishery. He proposed to cultivate plankton like a commercial crop.

Hensen's top candidate was Friedrich Heincke. He knew him personally, and appreciated him as a young, enthusiastic scientist. Of course he had read the publications of Heincke. In 1891 (the year he was appointed Director), Heincke published more than 32 monographs and articles. Later he became well-known in scientific circles through his monograph "Naturgeschichte des Herings" (Natural History of the Herring), published in 1898. He dedicated this work to a close friend, the President of the German Fishery Association, Walther Herwig (1838-1912).

Let me try to say a few words about the importance of the scientific work of Heincke. I hope you will excuse me if I do not go into detail. I am a biochemist and an historian, not 
a zoologist. I would like to mention some of Heincke's important ideas. For example: he tried to answer the question whether all North Sea herrings belong to one uniform species, or if there are local differences. He found out that there were numerous local forms, or "races".

Based on the results of his research, it was possible to follow the shoals of herring and to study their biology. He determined the term "race" with the help of anthropological methods, finding out the characteristics of several individuals and drawing conclusions for the general features and species. But Heincke was also active in other fields. He wrote books on the biology of plaice. In the past, the plaice had been very important for human nutrition. Based on his own research about the composition of plaice shoals (age, sex, etc.), and on the scientific findings of his colleagues, Heincke worked out a concept for the protection of this species of fish. However, his scientific research not only focussed on the scientific foundations of fishery, it was also closely connected to the economic aspects of it.

This was the reason why, finally, Friedrich Heincke was chosen to be Director of the Station.

Ehlers did not agree with the proposal, and regretted that priority had to be attached to the future commercial use of the station.

Heincke's main advantage as a candidate for the position was his excellent scientific work - but in Germany the quality of the work has never been the only reason for giving somebody a Chair. Famous historians compare the methods of selecting German professors with those used for appointing generals in the German Army. Indeed, there are close connections between the ideas of Scharnhorst and Humboldt, for example. We call it "Geschwisterideen" (related ideas). One had a genius for science, the other one had a genius for war - and both were outstanding people. The task was to identify people with

1. intellectual prowess;

2. creativity;

3. an ability to make quick decisions and to solve problems (Dupuy, 1977).

Eduard Spranger, Max Weber and Georg Schreiber published their ideas about the special role of German professors, and called them German "mandarins", influenced by German Idealism, especially by Kant and Goethe. With his Dr. Faustus, Goethe had created the ideal of a German Scientist as "Gralshüter". (the Knight of the Holy Grail). The typical German professor is an altruistic person, always endeavouring to find out the truth. This was also the opinion of the British historian John Theodore Merz in his book, "A History of European Thought in the Nineteenth Century". In fact, the biographer of Althoff, A. Sachse, stressed that Althoff was particularly fond of teachers, because school teachers never asked him for personal assistance in obtaining a position, or acquiring money - or anything else. On the contrary, they were always interested in organizing things for public welfare. However, anybody who takes a look at Atlhoff's papers in the archives in Merseburg will learn that scientists were considerably less altruistic than the school teachers whom Althoff so admired. In the case of Helgoland there was a special problem - this was the situation of the Island in winter. The famous Anton Dohrn warned Althoff that it would not be easy to find a creative man who would be willing to live far away from the amusements and diversions of the continent. By the way, Dohrn was not interested in founding the Helgoland station. You will find more details in my book, and I hope Ingeborg Müller will speak about some aspects of which I am presently unaware. 
Anyway, Heincke agreed to accept the post for only a small salary. He was creative; and his demands were modest.

How did he continue with his work during his time as a director? He went on with his research on the biology of plaice, and remained a creative and energetic scientist. He had a good feeling for "Zeitgeist". He encouraged the development of some new fields of research on Helgoland, and was willing to let his co-worker Hugo Weigold (1886-1973) change over from marine biology to ornithology. Weigold then founded the ornithological station on Helgoland. Heincke was a diplomat: he always tried to achieve the best for his institute. He loved his King more than his Republic, but he was able to adapt to the new conditions in the '20s. Together with Mielck, he fought for an extension of his institute, and allocated funds to build a new one. We should still remember that it was a period of world-wide recession.

Some people measure Heincke against Dohrn, the founder of the Marine Station at Naples. However, this does him an injustice. Heincke always had to consult his Ministry before being able to take any action. Nevertheless, he was productive, and displayed a humane attitude towards his co-workers, being diplomatic and tolerant. I think he was just the right man at the right time.

\section{LITERATURE CITED}

Dohrn, A. 1891, Letter to F. Althoff from 7. 4. 1891. Geheimes Staatsarchiv Preußischer Kulturbesitz, Rep. 76 Ya, Sekt. 1, Tit. xI, Teil II, Generalia, Wissenschaftssachen, wissenschaftliche Sachen, Nr. 10 a, p. 10.

Dupuy, T. N., 1977. A Genius for War - the German Army and General Staff, 1807-1945. MacDonald and Jane's, London, $362 \mathrm{pp}$.

Merz, J. T., 1965. A history of European thought in the nineteenth century, Vol. 1-4, Dover Publ., New York. (Repr, 1976. Smith, Gloucester, Mass.)

Ringer, F. K. 1969. The decline of the German mandarins. The German academic community, 1890-1933. Harvard University Press, Cambridge, Mass., 528 pp.

Sachse, A. 1928. Friedrich Althoff und sein Werk. Mittler, Berlin, $361 \mathrm{pp}$.

Werner, P. 1993. Die Gründung der Königlichen Biologischen Anstalt auf Helgoland und ihre Geschichte bis 1945. - Helgoländer Meeresunters. Vol. 47 (Suppl.), 1-182. 